\title{
Co-culturing bacteria and microalgae in organic carbon containing medium
}

\author{
Jichang Han ${ }^{1}$, Lin Zhang ${ }^{1,2}$, Song Wang ${ }^{1}$, Guanpin Yang ${ }^{3}$, Lu Zhao ${ }^{1}$ and Kehou Pan ${ }^{1,4^{*}}$
}

\begin{abstract}
Background: Microalgae frequently grow in natural environment and long-term laboratory cultures in association with bacteria. Bacteria benefit the oxygen and extracellular substances generated by microalgae, and reimburse microalgae with carbon dioxide, vitamins and so on. Such synergistic relationship has aided in establishing an efficient microalga-bacterium co-culturing mode. Obviously, the mutually beneficial relationship can be strengthened with the increase of the densities of microalgae and bacteria. However, nearly all of the early co-cultures were performed under photoautotrophic conditions, thus both microalgae and bacteria were at relatively low densities. In this study, the feasibility of bacteria-microalgae co-cultured under mixotrophic conditions was studied.

Results: Firstly, bacteria mingled with xenic microalgae were isolated and identified based on their 16S rRNA gene sequence (16S rDNA hereafter). Then, the two most frequently found strains of Muricauda sp. were co-cultured with axenic microalga (Tetraselmis chuii, Cylindrotheca fusiformis and Nannochloropsis gaditana) in extra organic carbon containing medium. At the end of a co-culture period of 33 days, we found that the final cell density of T. chuii and $C$. fusiformis of various treatments was remarkably higher than that of controls (21.37-31.18 and 65.42-83.47\%, respectively); on the contrary, the growth of N. gaditana was markedly inhibited. During the co-culture of bacteria with C. fusiformis, the cell density of two strains of bacteria firstly decreased, then increased and maintained at a relatively steady level. However, the cell density of bacteria performed a sustaining downward trend when they were co-cultured with T. chuii and N. gaditana.
\end{abstract}

Conclusions: Our findings proved that microalgae-bacteria co-cultures under mixotrophic conditions are quite effective strategy for microalgal cultivation.

Keywords: Microalgae, Bacteria, Microalgae-bacteria co-culture, Mixotrophy

\section{Background}

Microalgae and their valuable metabolites have the potential to be used as pollution control, food and feed additives, cosmetic, medicine production, etc. [1-3]. Moreover, microalgae are also considered to be the most appropriate feedstock of biofuel production. Diverse studies have been carried out to improve the efficiency of microalgal cultures (e.g., designing new photobioreactor, optimizing culture condition and reforming culture

\footnotetext{
*Correspondence: khpanouc@163.com

${ }^{4}$ Function Laboratory for Marin Fisheries Science and Food Production Processes, Qingdao National Laboratory for Marine Science and Technology, Qingdao 266237, China

Full list of author information is available at the end of the article
}

mode) and increase the content of high value substances (e.g., polyunsaturated fatty acid and neutral lipid) [4-9].

Microalgae and bacteria inhabit together almost all aquatic environments and play crucial roles in nutrient cycling and energy flowing. As documented early, bacteria highly influence the growth of microalgae under autotrophic conditions either positively or negatively [10-14]. In general, bacteria promote microalgal growth by (among others) reducing dissolved oxygen concentration, consuming the organic materials excreted by algae [15] and secreting biotin, cobalt amine and thiamine [16]. In turn, microalgae reimburse bacteria with oxygen and extracellular compounds. Such reciprocity implies that microalgal growth can be enhanced by specific bacteria $[10,11]$. 
Many microalgae can grow on light and chemical energy concurrently achieving extraordinarily high growth rate [17-21]. It is imaginable that the bacteria will compete with microalgae for nutrients, either organic or inorganic, when they are added into the mixotrophic cultivation system of microalgae. However, the competition can be abated by adding excessive nutrients or continuously adding nutrients. In other words, the reciprocity between microalgae and bacteria may still exist in such a co-culture system as was documented between bacteria and microalgae/cyanobacteria in wastewater treatment [3] and between probiotics and animals [22].

Tetraselmis chuii, Cylindrotheca fusiformis and Nannochloropsis gaditana are able to grow under mixotrophic conditions and can be cultured on a large scale [23-25]. Aiming to select bacteria that can promote microalgal growth, and to determine the feasibility of bacterium-microalga co-culture mode in organic carbon containing medium, we isolated and identified bacteria from xenic microalgal culture, and co-cultured the two most abundant bacteria with these three axenic microalgae each in medium containing organic substances. The growth performances of microalgae and bacteria were investigated during a co-culture period of 33 days, and the feasibility of such cultivation strategy was discussed.

\section{Results}

\section{Isolation and identification of bacteria}

In total, 43 bacterial strains were isolated from 16 xenic microalgal strains and they were assigned to 19 genera. Most of them were identified in classes Bacteroidetes, Flavobacteria, $\alpha$-proteobacteria, and $\gamma$-proteobacteria (Table 1). Though these xenic microalgae have been domesticated in laboratory for many years, their bacterial communities were still similar to those of marine environments [26]. The bacterial species in association with different microalgae varied to a relatively large extent suggesting a possible interaction between specific microalgae and bacteria (Table 1) [27, 28]. Muricauda sp. which co-existed with 13 of 16 microalgal strains, was found to be the most ubiquitous bacteria (Table 2). All 16 xenic microalgal strains grew well in long-term laboratory culture. As a result, it was inferred that the ubiquitous bacteria survived together with most microalgae were possible to promote microalgal growth. Accordingly, two strains of Muricauda sp., Mur1 [GenBank: KM23334] and Mur2 [GenBank: KM23335], were chosen to co-culture with the three selected microalgae.

\section{Growth curves of Mur1 and Mur2}

The density of Mur1 and Mur2 each maximized at $72 \mathrm{~h}$ $\left(1.2 \times 10^{10}\right.$ and $6.5 \times 10^{9} \mathrm{CFU} \mathrm{mL} \mathrm{m}^{-1}$, respectively), then drastically declined to $4.0 \times 10^{8}$ and $5.2 \times 10^{8} \mathrm{CFU} \mathrm{mL}^{-1}$ at $96 \mathrm{~h}$ (Fig. 1) suggesting that the bacteria after reaching the maximal density might begin to secrete extracellular substances, which would affect the microalgal growth. As a result, Mur1 and Mur2 cultured for $24 \mathrm{~h}$, with relatively low concentration and high metabolic activity, were determined for use in the following co-culture phase.

\section{Detection of extra bacterial contamination}

No different bacterial colony was observed on the plates, and the sequencing results of co-inoculated samples were consistent with that of Mur1 or Mur2 indicating that all treatments have not been contaminated by external bacteria.

\section{Growth performance of bacterium during co-culture}

For the combinations of Mur1, Mur2 and T. chuii, the bacterial densities of all treatments have drastically reduced in first 9 days, and remained at relatively low levels since then. Despite the initial density of different treatments varied greatly, their final density was similar to each other (Fig. 2a, b).

In co-culturing Mur1 and C. fusiformis, the bacterium of treatment one presented a transient increase in first 6 days, decreased to the minimum on the day 15 , then displayed a slight increase and maintained at a relatively stable state (around $4.5 \times 10^{7} \mathrm{CFU} \mathrm{mL}{ }^{-1}$ ). The variation of bacterial density of treatment two and three was similar to each other; both decreased firstly, and then increased to a relatively stable amount (around $4.5 \times 10^{7} \mathrm{CFU} \mathrm{mL}{ }^{-1}$ ). The overall variation trend of three treatments of Mur2 was quite similar to those of Mur1 (Fig. 2c, d).

The cell density of bacterium added into $N$. gaditana has been traced for 9 days. As shown in Fig. 2e and f, the variation trends of Mur1 and Mur2 was quite similar to those of C. fusiformis.

\section{Growth performances of microalgae during co-culture}

As shown in Fig. 3, the growth performance of three microalga changed greatly during co-culture. Mur1 and Mur2 promoted the growth of T. chuii and C. fusiformis heavily, but inhibited the growth of $N$. gaditana drastically.

The final cell density of $T$. chuii co-cultured with Mur1 or Mur2 was higher than that of control. Three treatments co-cultured with Mur1 increased the final cell density of $T$. chuii by 21.37 to $23.91 \%$ (the highest was $5.68 \times 10^{6}$ cells $\mathrm{mL}^{-1}$ ). For Mur2, the improvement ranged from $28.63 \%$ to $31.18 \%$ (the highest was $6.01 \times 10^{6}$ cells $\mathrm{mL}^{-1}$ ) (Fig. 3a, b). The enhancement of Mur1 and Mur2 to the growth of C. fusiformis was much greater than that to T. chuii. When co-cultured 
Table 1 Bacterial species isolated from mixotrophically cultured microalgae

\begin{tabular}{|c|c|c|c|c|c|}
\hline Closest relative & Strains & Similarity (\%) & E-value & Acc. no. & Classes \\
\hline \multirow[t]{10}{*}{ Muricauda sp. } & Mur1 & 99 & 0.0 & JN594619 & Bacteroidetes \\
\hline & Mur2 & 99 & 0.0 & KF724486 & Bacteroidetes \\
\hline & Mur3 & 99 & 0.0 & JN594619 & Bacteroidetes \\
\hline & Mur4 & 99 & 0.0 & JN594619 & Bacteroidetes \\
\hline & Mur5 & 99 & 0.0 & JN594619 & Bacteroidetes \\
\hline & Mur6 & 99 & 0.0 & JN594619 & Bacteroidetes \\
\hline & Mur7 & 100 & 0.0 & EU839357 & Bacteroidetes \\
\hline & Mur8 & 99 & 0.0 & AY576776 & Bacteroidetes \\
\hline & Mur9 & 99 & 0.0 & EU839357 & Bacteroidetes \\
\hline & Mur10 & 99 & 0.0 & EU839357 & Bacteroidetes \\
\hline \multirow[t]{5}{*}{ M. aquimarina } & Mur11 & 100 & 0.0 & KC534238 & Bacteroidetes \\
\hline & Mur12 & 99 & 0.0 & KF500394 & Bacteroidetes \\
\hline & Mur13 & 100 & 0.0 & KF500394 & Bacteroidetes \\
\hline & Mur14 & 99 & 0.0 & KF500397 & Bacteroidetes \\
\hline & Mur15 & 99 & 0.0 & NR_042909 & Bacteroidetes \\
\hline \multirow[t]{2}{*}{ Bacteroidetes bacterium } & $\mathrm{Bac1}$ & 99 & 0.0 & AY162097 & Flavobacteria \\
\hline & Bac2 & 99 & 0.0 & GU565603 & Flavobacteria \\
\hline Flavobacterium sp. & Fla1 & 100 & 0.0 & AF386740 & Flavobacteria \\
\hline Aestuariibacter sp. & Aes1 & 99 & 0.0 & JF309276 & ү-proteobacteria \\
\hline \multirow[t]{2}{*}{ Marinobacter sp. } & Mar1 & 100 & 0.0 & AB758589 & ү-proteobacteria \\
\hline & Mar2 & 99 & 0.0 & AM944524 & ү-proteobacteria \\
\hline M. flavimaris & Mar3 & 100 & 0.0 & AB617558 & ү-proteobacteria \\
\hline M. hydrocarbonoclasticus & Mar4 & 99 & 0.0 & JQ799112 & ү-proteobacteria \\
\hline M. radhaerens & Mar5 & 100 & 0.0 & NR_074765 & ү-proteobacteria \\
\hline \multirow[t]{2}{*}{ Alteromonas sp. } & Alt1 & 99 & 0.0 & AB636144 & ү-proteobacteria \\
\hline & Alt2 & 99 & 0.0 & AB636144 & ү-proteobacteria \\
\hline \multirow[t]{2}{*}{ Pseudoalteromonas sp. } & Pse1 & 98 & 0.0 & GQ495024 & ү-proteobacteria \\
\hline & Pse2 & 99 & 0.0 & GQ495024 & ү-proteobacteria \\
\hline \multirow[t]{2}{*}{ Nitratireductor sp. } & Nit1 & 99 & 0.0 & JN942153 & a-proteobacteria \\
\hline & Nit2 & 99 & 0.0 & JN942153 & a-proteobacteria \\
\hline Stappia sp. & Sta1 & 100 & 0.0 & JF899875 & a-proteobacteria \\
\hline Stappia indica & Sta2 & 99 & 0.0 & AB607882 & a-proteobacteria \\
\hline Labrenzia aggregata & Lab1 & 99 & 0.0 & AB681109 & a-proteobacteria \\
\hline Maricaulis parjimensis & Mac1 & 99 & 0.0 & NR_025323 & a-proteobacteria \\
\hline Zhangella mobilis & Zha1 & 99 & 0.0 & EU255260 & a-proteobacteria \\
\hline Oceanicaulis sp. & Oce1 & 100 & 0.0 & AB681546 & a-proteobacteria \\
\hline Sagittula sp. & Sag1 & 99 & 0.0 & KC534267 & a-proteobacteria \\
\hline Tropicibacter sp. & Tro1 & 98 & 0.0 & KC534265 & a-proteobacteria \\
\hline \multirow[t]{2}{*}{ Rhodopirellula baltica } & Rho1 & 100 & 0.0 & JN694985 & Planctomycetacia \\
\hline & Rho2 & 99 & 0.0 & HQ845537 & Planctomycetacia \\
\hline Cytophaga sp. & Cyt1 & 98 & 0.0 & AB073564 & Sphingobacteria \\
\hline Kocuria rosea & Koc1 & 99 & 0.0 & JN192402 & Actinobacteria \\
\hline Bacillus jeotgali & Bai1 & 99 & 0.0 & JX094165 & Firmicutes \\
\hline
\end{tabular}

Acc. no., accession number of GenBank

with Mur1 and Mur2, the cell density of C. fusiformis increased by about 80 and $65 \%$ over control, respectively (the highest cell density was 9.62 and $8.73 \times 10^{6}$ cells $\mathrm{mL}^{-1}$, respectively) (Fig. 3c, d).
Such promotion was not found in N. gaditana. Instead of enhancement, the growth of $N$. gaditana of all treatments was obviously inhibited by Mur1 and Mur2 (Fig. 3e, f). The inhibitory effect of Mur1 on $N$. gaditana was greater than 
Table 2 Bacteria and corresponding microalgae

\begin{tabular}{|c|c|c|c|c|c|c|c|c|c|c|c|c|c|c|c|c|}
\hline Bacterial species & 1 & 2 & 3 & 4 & 5 & 6 & 7 & 8 & 9 & 10 & 11 & 12 & 13 & 14 & 15 & 16 \\
\hline Muricauda sp. & + & & & + & + & + & + & + & + & + & + & + & & + & + & + \\
\hline Bacteroidetes bacterium & & + & & + & + & & + & + & & + & + & + & + & + & & + \\
\hline Flavobacterium sp. & + & + & & & & + & & + & + & & & + & & & & \\
\hline Aestuariibacter sp. & & & & + & & & & & & & + & & & & + & \\
\hline Marinobacter sp. & + & & & & + & + & + & & + & + & & & + & & & \\
\hline Alteromonas sp. & & + & & & & & & & & & & + & + & + & & \\
\hline Pseudoalteromonas sp. & + & & + & & & + & & + & + & & & & & & & + \\
\hline Nitratireductor sp. & & & + & + & + & & & + & & + & + & & + & & + & + \\
\hline Stappia sp. & & & & + & + & & + & & & & & + & + & & & + \\
\hline Labrenzia aggregata & & + & + & & & & + & & & & & & & & + & \\
\hline Maricaulis parjimensis & & & & + & + & + & & & & & + & + & + & + & & + \\
\hline Zhangella mobilis & & & & & & & & & & & & & & + & & \\
\hline Oceanicaulis sp. & + & + & & & & & & + & + & & & + & & & & \\
\hline Sagittula sp. & & & & & & + & & & & & & + & & + & + & \\
\hline Tropicibacter sp. & & & & & & & & & & & + & & + & & & + \\
\hline Rhodopirellula baltica & & & & & & & & & & & & + & & + & & \\
\hline Cytophaga sp. & & & & & & & & & & & & + & + & & + & \\
\hline Kocuria rosea & & & & & & & & & & & & & & + & + & + \\
\hline Bacillus jeotgali & & & & & & & & & & & + & & & + & + & \\
\hline
\end{tabular}

Numbers from 1 to 16 stand for the xenic microalgal strains used in this study, 1: Nannochloropsis oceanic; 2: N. gaditana; 3: N. oculata; 4: Thalassiosira sp.; 5: Chaetoceros gracilis; 6: Navicula sp.; 7: Cylindrotheca fusiformis; 8: Phaeodactylum tricornutum; 9: Pseudo-nitzschia sp.; 10: Pavlova sp.; 11: Chromulina sp.; 12: Gymnodinium sp.; 13: Amphidinium carterae; 14: Prorocentrum minimum; 15: Karenia mikimotoi; 16: Heterosigma carterae

+ , bacterium was obtained; margin, bacterium was not isolated

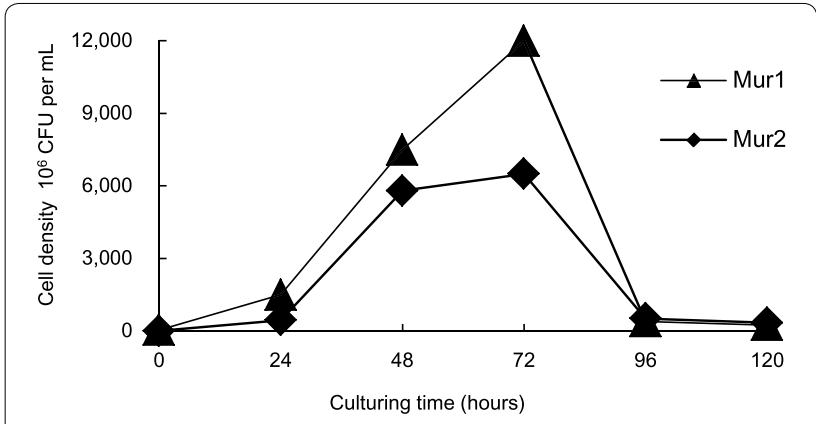

Fig. 1 Growth curves of Mur1 and Mur2. Error bars are too small to be seen

that of Mur2. Microscopic observation showed that some cells of $N$. gaditana started to rupture on day 5 .

\section{Discussion}

In the present study, the positive effect of selected bacteria on the growth of microalgae was observed, indicating the co-culture mode of microalgae-bacteria in the organic substance containing medium was feasible and highly efficient. On the other hand, the results of the present study indicated that specific bacteria can drastically inhibit the growth of specific microalgae, as in the case of $N$. gaditana. The phenomenon of specific bacterium induce different effect on different microalgae has been reported earlier $[29,30]$, which indicated that the determination of suitable combination of microalga and bacterium was quite important for the successful implementation of co-culture mode.

In general, bacterial metabolism can benefit microalgal growth by providing favorable microenvironments, e.g., increasing carbon dioxide, secreting vitamins and reducing photosynthetic oxygen tension [16, 31, 32]. Obviously, such beneficial effects will be enhanced by increasing bacterial density as it has been demonstrated by the results of the present study. For example, the higher the initial concentration of Mur1, the faster the growth of $C$. fusiformis in the early phase of co-culture (day 2-8). By consuming the original organic substance, the bacterial density of all treatments reduced and maintained at a similar level, which further resulted in a similar microalgal growth rate and a final microalgal density among all treatments. Such observation is in contrast to previous reports [33]. The relatively sufficient nutrient in our culture system may have alleviated the competition between microalga and bacterium, thus being responsible for this difference.

Except for positive effect, drastically inhibition phenomenon was also observed. Overall, the bacterium can restrain the microalgal growth by several ways 

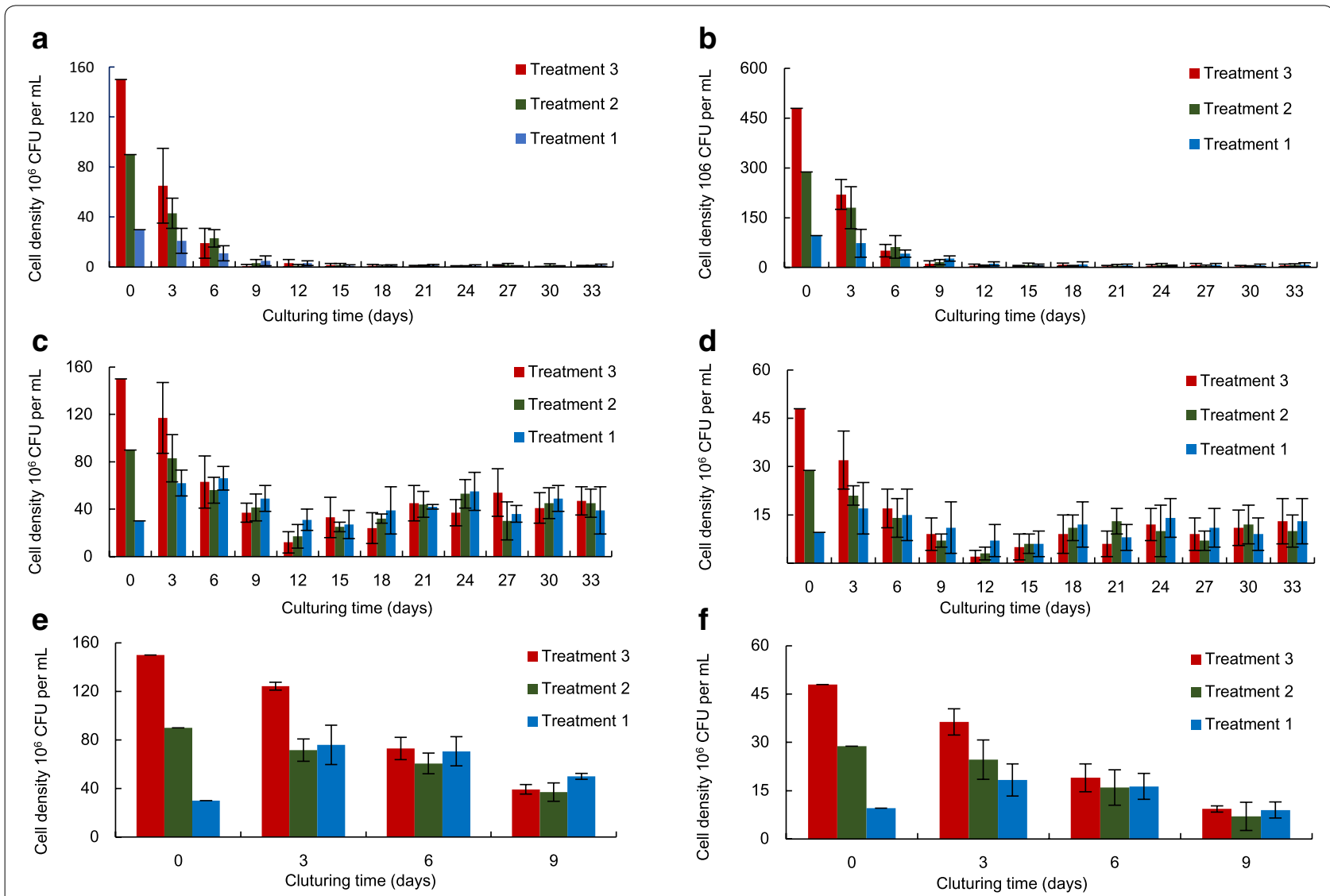

Fig. 2 Growth performances of Mur1 and Mur2 during co-culture. Mur1 and Mur2 co-cultured with T. chuii (a, b); C. fusiformis (c, d); N. gaditana (e, f), respectively

including (among others) the competition for nutrients [34-36], the excretion of algicidal substances [37-39], and the degradation of the cell wall of the microalgal cell through direct contact [40-42]. For the combination of Mur1/Mur2 and N. gaditana, several phenomena can be detected. For example, the microalgal density of all treatments was obviously lower than that of control except at day 3; the inhibitory effect of bacteria on $N$. gaditana enhanced with the increase of the original bacterial concentration; the bacterial densities of all groups except the combinations of $N$. gaditana and Mur1/Mur2 at the ratios of 1.96/0.59 declined all the time; and the cells of $N$. gaditana began to rupture after 5 days of co-culture. As a result, it can be inferred that the inhibitory effect was caused by direct contact, and such effect may appear as long as the density ratio of bacterium to microalgae reached a certain threshold.

During co-culture, not only the density of microalgae changed greatly, but also the concentration of bacteria experienced large fluctuations. Following the consumption of the original organic substance, the concentration of bacterium of nearly all treatments shared a common declining trend in first 9 days. As the incubation time prolonged, the variation trend of bacterial density among different combinations began to diverge, either continuously declining ( $T$. chuii) or steadily rising (C. fusiformis). Such obvious discrepancy can come down to the difference of excreting extracellular substances between a benthic diatom and a green alga. In addition, the compounds secreted by $T$. chuii may also play a role on the continuous decline of bacterial density as it has been observed in other microalgae [43-45].

Based on our results, it can be deduced that bacteria and microalgae interacted each other when they were co-cultured in the medium containing extra organic substance. Screening bacteria capable of promoting microalgal growth is relatively simple. However, it needs more attention to determine an optimum candidate for a specific microalga. For example, the final density of $C$. fusiformis was around 80 and $65 \%$ higher than that of control when it was co-cultured with Mur1 and Mur2, respectively; however, the promotion became around 23 and $30 \%$ for $T$. chuii. This difference was possibly caused by different performances of bacteria and microalgae in 

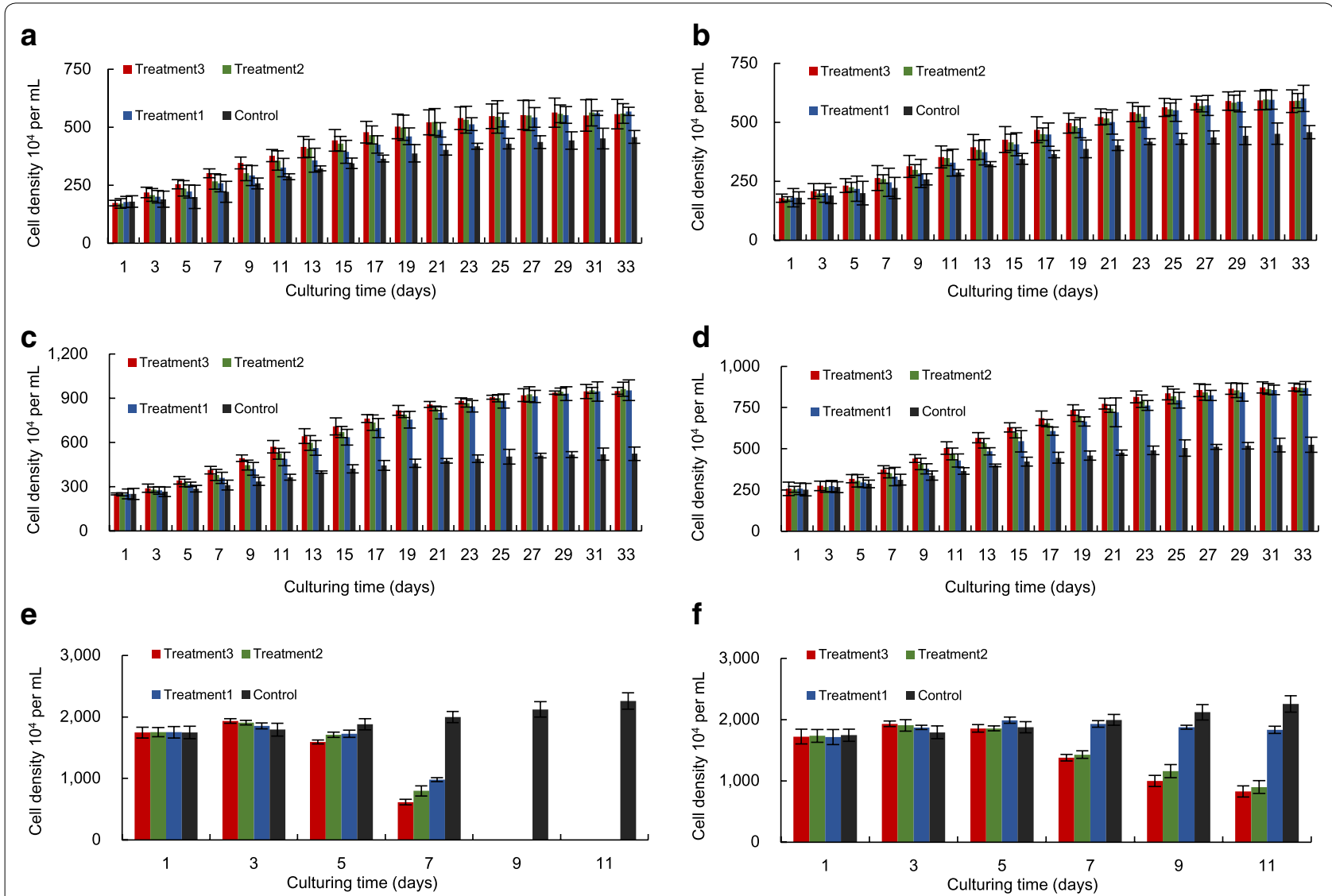

f

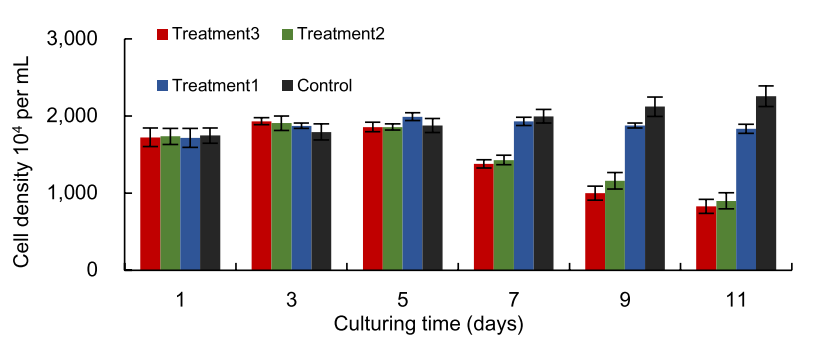

Fig. 3 Performance of three microalga during co-culture. T. chuii (a, b), C. fusiformis (c, d) and N. gaditana (e, f) co-cultured with Mur1 and Mur2

the ability of competing for nutrients (both organic and inorganic), the respiratory and photosynthetic rate and the kind and amount of excreting substance.

\section{Methods}

\section{Microalgal strains}

Sixteen xenic microalgal strains (Table 2) were obtained from the culture collection of microalgae of Ocean University of China, and cultured in $\mathrm{f} / 2$ seawater medium [46] at $25 \pm 1{ }^{\circ} \mathrm{C}$ and under $70 \mu \mathrm{mol}$ photons $\mathrm{m}^{-2} \mathrm{~s}^{-1}$ irradiation with a photoperiod of $12 \mathrm{~h}$ light and $12 \mathrm{~h}$ dark. Three axenic microalgae (T. chuii, C. fusiformis and $N$. gaditana) were obtained as described previously [47]. The axenic algal cells stained by SYBR Green I (Solarbio, China) were examined under fluorescence microscope $[47,48]$.

\section{Isolation and preliminary identification of bacteria}

Microalgae in stationary growth phase were inoculated into fresh $\mathrm{f} / 2$ medium at a ratio of $1 / 10(\mathrm{v} / \mathrm{v})$ and cultured for 20 days. One $\mathrm{mL}$ of microalgal culture was 1000 fold diluted with sterile $\mathrm{f} / 2$ medium. Then, $1 \mathrm{~mL}$ of the dilution was mixed with $25 \mathrm{~mL}$ of sterile 2216E marine bacterium solid culture medium (1.5\% agar containing), poured into Petri dish and cultured at $37^{\circ} \mathrm{C}$ for $72 \mathrm{~h}$. In total, 15 colonies were picked up from each plate, and inoculated into $2 \mathrm{~mL}$ of $2216 \mathrm{E}$ liquid medium and cultured at $37{ }^{\circ} \mathrm{C}$ and $200 \mathrm{rpm}$ for one day. After that, the culture was streaked and cultured for 3 days. A single colony was picked up and inoculated into $2 \mathrm{~mL}$ of $2216 \mathrm{E}$ medium and cultured for 2 days. One $\mathrm{mL}$ of each culture was stored at $-80^{\circ} \mathrm{C}$ in $20 \%$ of glycerol (v/v) and the rest $1 \mathrm{~mL}$ was used to extract DNA with CTAB method [49]. The universal primers for the amplification of $16 \mathrm{~S}$ rRNA gene used in this study were listed in Table 3 . In this procedure, primers of $27 \mathrm{~F}$ and $1492 \mathrm{R}$ were preferred, and the pairs of $63 \mathrm{~F}$ and WBAC2, E9F and 1542R were taken as alternatives.

PCR was carried out on a thermocycler (Eppendorf, Germany) with a cycling regime of (1) one cycle of $5 \mathrm{~min}$ at $94{ }^{\circ} \mathrm{C}$, (2) 30 cycles of each $30 \mathrm{~s}$ at $94{ }^{\circ} \mathrm{C}, 30 \mathrm{~s}$ at $50{ }^{\circ} \mathrm{C}$, and $1.5 \mathrm{~min}$ at $72{ }^{\circ} \mathrm{C}$, and (3) $10 \mathrm{~min}$ at $72{ }^{\circ} \mathrm{C}$. The final volume of PCR mix was $50 \mu \mathrm{L}$ containing $25 \mu \mathrm{L}_{\text {Easy Taq }}{ }^{\circledR}$ PCR SuperMix (TransGen Biotech, Beijng, China), $1 \mu \mathrm{L}$ of each primer $(0.2 \mu \mathrm{M}), 2 \mu \mathrm{L}$ DNA template and $11 \mu \mathrm{L}$ $\mathrm{dd}_{2} \mathrm{O}$. PCR products were purified with OMEGA Gel 
Table 3 Primers used for the amplification and sequencing of 16S rRNA

\begin{tabular}{lll}
\hline Primers & Sequences $\left(\mathbf{5}^{\prime} \mathbf{- 3}^{\prime}\right)$ & References \\
\hline $27 \mathrm{~F}$ & AGAGTTTGATCCTGGCTCAG & {$[50]$} \\
$1492 \mathrm{R}$ & CGGCTACCTTGTTACGACTT & {$[50]$} \\
$63 \mathrm{~F}$ & CAGGCCTAACACATGCAAGTC & {$[51]$} \\
WBAC2 & CCCGGGAACGTATTCACCGCG & {$[51]$} \\
E9F & GAGTTTGATCCTGGCTCAG & {$[52]$} \\
$1542 \mathrm{R}$ & AGAAAGGAGGTGATCCARCC & {$[53]$} \\
\hline
\end{tabular}

Extraction Kit (OMEGA, USA) and subsequent samples were sent to Sango Company (Shanghai, China) for sequencing.

Primary determination of growth curves of Mur1 and Mur2 Many bacteria secrete extracellular substances after reaching their maximum densities [54]. To reduce the effects of such potential substances on microalgal growth as much as possible, the growth curves of the two most abundant bacterial strains, Mur1 and Mur2, were drawn ahead of co-culture.

One hundred $\mu \mathrm{L}$ of bacterial culture maintained at $-80{ }^{\circ} \mathrm{C}$ were transferred to $400 \mathrm{~mL}$ of $2216 \mathrm{E}$ medium, cultured at $37{ }^{\circ} \mathrm{C}$ and $200 \mathrm{rpm}$ for $120 \mathrm{~h}$. During this period, one $\mathrm{mL}$ of culture was taken every day and it was tenfold diluted. Then, $1 \mathrm{~mL}$ of the dilution was mixed with $25 \mathrm{~mL}$ of $2216 \mathrm{E}$ marine bacterium solid medium and cultured under the same conditions as above for $72 \mathrm{~h}$ with colonies counted. Plates with 20-200 colonies were chosen to calculate the bacterial density using the equation: bacterial density $\left(\mathrm{CFU} \mathrm{mL} \mathrm{m}^{-1}\right)=$ colony number $\times$ dilution fold.

\section{Algae-bacteria co-culture}

Four $\mathrm{mL}$ of axenic microalgae each in stationary growth phase, in which the cell density of $T$. chuii, C. fusiformis and $N$. gaditana was about $2.0 \times 10^{6}, 2.8 \times 10^{6}$ and $1.9 \times 10^{7}$ cells $\mathrm{mL}^{-1}$, respectively, were inoculated into $41 \mathrm{~mL}$ of fresh $\mathrm{f} / 2$ medium and cultured at $25 \pm 1{ }^{\circ} \mathrm{C}$ and under $70 \mu \mathrm{mol}$ photons $\mathrm{m}^{-2} \mathrm{~s}^{-1}$ irradiation under a light cycle of $12 \mathrm{~h}$ light and $12 \mathrm{~h}$ dark for 15 days. The final cell density was determined with a hemocytometer (Qiujing, Shanghai, China).

One hundred $\mu \mathrm{L}$ of Mur1 and Mur2 maintained at $-80{ }^{\circ} \mathrm{C}$ were inoculated into $400 \mathrm{~mL}$ of fresh $2216 \mathrm{E}$ medium and cultured at $37{ }^{\circ} \mathrm{C}$ and $200 \mathrm{rpm}$ for $24 \mathrm{~h}$. The bacterial density was determined with the method described above.

Afterwards, $1 \mathrm{~mL}$ (treatment 1), $3 \mathrm{~mL}$ (treatment 2), and $5 \mathrm{~mL}$ (treatment 3 ) of the bacteria were collected by
Table 4 Initial ratios of bacterial to microalgal cell numbers

\begin{tabular}{lccc}
\hline Ratios & Treatment 1 & Treatment 2 & Treatment 3 \\
\hline Mur 1 : T. chuii & 19.61 & 58.82 & 98.04 \\
Mur 1 : C. fusiformis & 13.33 & 40.00 & 66.67 \\
Mur 1 : N. gaditana & 1.96 & 5.88 & 9.80 \\
Mur 2 : T. chuii & 5.88 & 17.65 & 29.41 \\
Mur 2 : C. fusiformis & 4.00 & 12.00 & 20.00 \\
Mur 2 : N. gaditana & 0.59 & 1.76 & 2.94 \\
\hline
\end{tabular}

centrifugation and suspended in $5 \mathrm{~mL}$ modified $2216 \mathrm{E}$ medium ( $1 \mathrm{~L}$ seawater containing $5.0 \mathrm{~g}$ peptone, $1.0 \mathrm{~g}$ yeast extract, $1.0 \mathrm{~g}$ glucose and $0.1 \mathrm{~g} \mathrm{FePO}_{4}$ ), mixed with $45 \mathrm{~mL}$ of axenic microalgal culture. Microalgae each mixed with $5 \mathrm{~mL}$ of modified 2216E medium were cultured as controls. The microalgae/bacteria density was investigated every $2 / 3$ days respectively, with the method described above. The initial density ratios of bacteria to microalgae of various treatments were listed in Table 4.

\section{Verification of bacterial contamination}

On the last day of co-culture, $1 \mathrm{~mL}$ of 1000 -fold dilution of microalgal culture was mixed with $2216 \mathrm{E}$ solid medium and cultured under the same conditions as above for 3 days. Thirty bacterial colonies were picked from each plate randomly and co-inoculated into $2 \mathrm{~mL}$ of $2216 \mathrm{E}$ and cultured for 2 days. The $16 \mathrm{~S}$ rDNA was amplified with primer $27 \mathrm{~F}$ and $1492 \mathrm{R}$, sequenced and used to perform a local alignment (Bioedit) with the sequences of Mur1/Mur2.

\section{Conclusions}

Compared to autotrophic culturing system, additional organic nutrients in our co-culturing system yielded higher cell densities of both microalgae and bacteria. As a result, the effect of bacteria on microalgae, either positive or negative, was heavily intensified. Such co-culture mode was quite different from those documented early displaying obvious enhancements on the growth of $T$. chuii and C. fusiformis, which was potential to be used in microalgal cultivation.

\section{Authors' contributions}

HJC designed and conducted the experiment, collected and analyzed the data and wrote the manuscript. ZL (Lin Zhang) participated in designing the study and offered assistance in laboratory work. WS and ZL (Lu Zhao) contributed to revise draft and prepare figures. YGP provided suggestions and instructions on experiment designing and draft revising. PKH contributed to design the study. All authors read and approved the final manuscript.

\footnotetext{
Author details

${ }^{1}$ Laboratory of Applied Microalgae Biology, Ocean University of China, Qingdao 266003, China. ${ }^{2}$ Key Laboratory of Marine Biotechnology, Ningbo University, Ningbo 315211, China. ${ }^{3}$ College of Marine Life Sciences, Ocean
} 
University of China, Qingdao 266003, China. ${ }^{4}$ Function Laboratory for Marin Fisheries Science and Food Production Processes, Qingdao National Laboratory for Marine Science and Technology, Qingdao 266237, China.

\section{Acknowledgements}

This work was supported by the Major State Basic Research Development Program of China (973 Program) (2011CB200901) and National Technical Supporting Project Foundation (2011BAD14B01) and National High Technology Research and Development Program of China (863 Program) (2013AA065801).

\section{Competing interests}

The authors declare that they have no competing interests.

Received: 19 September 2015 Accepted: 1 April 2016

Published online: 26 April 2016

\section{References}

1. Kumar A, Ergas S, Yuan X, Sahu A, Zhang Q, Dewulf J, et al. Enhanced $\mathrm{CO}_{2}$ fixation and biofuel production via microalgae: recent developments and future directions. Trends Biotechnol. 2010;28:371-80.

2. Rosenberg JN, Oyler GA, Wilkinson L, Betenbaugh MJ. A green light for engineered algae: redirecting metabolism to fuel a biotechnology revolution. Curr Opin Biotechnol. 2008;19:430-6.

3. Subashchandrabose SR, Ramakrishnan B, Megharaj M, Venkateswarlu K, Naidu R. Consortia of cyanobacteria/microalgae and bacteria: biotechnological potential. Biotechnol Adv. 2011;29:896-907.

4. Adarme-Vega TC, Lim DK, Timmins M, Vernen F, Li Y, Schenk PM. Microalgal biofactories: a promising approach towards sustainable omega-3 fatty acid production. Microbial Cell Fact. 2012:11:96.

5. Bougaran G, Bernard O, Sciandra A. Modeling continuous cultures of microalgae colimited by nitrogen and phosphorus. J Theor Biol. 2010;265:443-54

6. El-Sheekh MM, Bedaiwy MY, Osman ME, Ismail MM. Mixotrophic and heterotrophic growth of some microalgae using extract of fungal-treated wheat bran. Int J Recycl Org Waste Agric. 2012;1:12

7. Gonzalez LE, Bashan Y. Increased growth of the microalga Chlorella vulgaris when coimmobilized and cocultured in alginate beads with the plant-growth-promoting bacterium Azospirillum brasilense. Appl Environ Microbiol. 2000;66:1527-31.

8. Sharma KK, Schuhmann H, Schenk PM. High lipid induction in microalgae for biodiesel production. Energies. 2012;5:1532-53.

9. Cheng-Wu Z, Zmora O, Kopel R, Richmond A. An industrial-size flat plate glass reactor for mass production of Nannochloropsis sp. (Eustigmatophyceae). Aquaculture. 2001:195:35-49.

10. de-Bashan LE, Bashan Y, Moreno M, Lebsky VK, Bustillos JJ. Increased pigment and lipid content, lipid variety, and cell and population size of the microalgae Chlorella spp. when co-immobilized in alginate beads with the microalgae-growth-promoting bacterium Azospirillum brasilense. Can J Microbiol. 2002:48:514-21.

11. Ethier S, Woisard K, Vaughan D, Wen Z. Continuous culture of the microalgae Schizochytrium limacinum on biodiesel-derived crude glycerol for producing docosahexaenoic acid. Bioresour Technol. 2011:102:88-93.

12. Lorincz Z, Preininger E, Kósa A, Pónyi T, Nyitrai T, Sarkadi L, et al. Artificial tripartite symbiosis involving a green alga (Chlamydomonas), a bacterium (Azotobacter) and a fungus (Alternaria): morphological and physiological characterization. Folia Microbiol (Praha). 2010:55:393-400.

13. Ortiz-Marquez JC, Do Nascimento M, Dublan Mde L, Curatti L. Association with an ammonium-excreting bacterium allows diazotrophic culture of oil-rich eukaryotic microalgae. Appl Environ Microbiol. 2012;78:2345-52.

14. Rivas MO, Vargas P, Riquelme CE. Interactions of Botryococcus braunii cultures with bacterial biofilms. Microb Ecol. 2010;60:628-35.

15. Mouget J-L, Dakhama A, Lavoie MC, de la Noüe J. Algal growth enhancement by bacteria: is consumption of photosynthetic oxygen involved? FEMS Microbiol Ecol. 1995;18:35-43.

16. Croft MT, Lawrence AD, Raux-Deery E, Warren MJ, Smith AG. Algae acquire vitamin $B_{12}$ through a symbiotic relationship with bacteria. Nature $2005 \cdot 438 \cdot 90-3$.
17. Brennan $L$, Owende P. Biofuels from microalgae-a review of technologies for production, processing, and extractions of biofuels and coproducts. Renew Sustain Energ Rev. 2010;14:557-77.

18. Burkholder JM, Glibert PM, Skelton HM. Mixotrophy, a major mode of nutrition for harmful algal species in eutrophic waters. Harmful Algae. 2008;8:77-93.

19. Lee Y-K. Microalgal mass culture systems and methods: their limitation and potential. J Appl Phycol. 2001;13:307-15.

20. Liang Y, Sarkany N, Cui Y. Biomass and lipid productivities of Chlorella vulgaris under autotrophic, heterotrophic and mixotrophic growth conditions. Biotechnol Lett. 2009:31:1043-9.

21. Yang C, Hua Q, Shimizu K. Energetics and carbon metabolism during growth of microalgal cells under photoautotrophic, mixotrophic and cyclic light-autotrophic/dark-heterotrophic conditions. Biochem Eng J. 2000;6:87-102.

22. Fuller R. Probiotics in man and animals. J Appl Bacteriol. 1989;66:365-78.

23. Lowrey J, Brooks MS, McGinn PJ. Heterotrophic and mixotrophic cultivation of microalgae for biodiesel production in agricultural wastewaters and associated challenges - a critical review. J Appl Phycol. 2015:27:1485-98.

24. Suman K, Kiran T, Devi UK, Sarma NS. Culture medium optimization and lipid profiling of Cylindrotheca, a lipid-and polyunsaturated fatty acid-rich pennate diatom and potential source of eicosapentaenoic acid. Bot Mar. 2012;55:289-99.

25. Xu F, Hu HH, Cong W, Cai ZL, Ouyang F. Growth characteristics and eicosapentaenoic acid production by Nannochloropsis sp. in mixotrophic conditions. Biotechnol Lett. 2004:26:51-3.

26. Kirchman DL. The ecology of Cytophaga-Flavobacteria in aquatic environments. FEMS Microbiol Ecol. 2002:39:91-100.

27. Rooney-Varga JN, Giewat MW, Savin MC, Sood S, LeGresley M, Martin JL. Links between phytoplankton and bacterial community dynamics in a coastal marine environment. Microb Ecol. 2005;49:163-75.

28. Sapp M, Schwaderer AS, Wiltshire KH, Hoppe HG, Gerdts G, Wichels A. Species-specific bacterial communities in the phycosphere of microalgae? Microb Ecol. 2007;53:683-99.

29. Baggesen C. A study of microalgal symbiotic communities with the aim to increase biomass and biodiesel production. Ph.D Thesis. 2014. Copenhagen: Technical University of Denmark.

30. Suminto Hirayama K. Application of a growth-promoting bacteria for stable mass culture of three marine microalgae. Hydrobiologia. 1997;358:223-30

31. Fukami K, Nishijima T, Ishida Y. Stimulative and inhibitory effects of bacteria on the growth of microalgae. Hydrobiologia. 1997;358:185-91.

32. Watanabe KJ, Takihana N, Aoyagi H, Hanada S, Watanabe Y, Ohmura N, et al. Symbiotic association in Chlorella culture. FEMS Microbiol Ecol. 2005:51:187-96.

33. Qu L, Wang R, Zhao P, Chen R, Zhou W, Tang L, et al. Interaction between Chlorella vulgaris and bacteria: interference and resource competition. Acta Oceanol Sin. 2014:33:135-40.

34. Grossart H-P. Interactions between marine bacteria and axenic diatoms (Cylindrotheca fusiformis, Nitzschia laevis and Thalassiosira weissflogii) incubated under various conditions in the lab. Aquat Microb Ecol. 1999;19:1-11.

35. Gurung TB, Urabe J, Nakanishi M. Regulation of the relationship between phytoplankton Scenedesmus acutus and heterotrophic bacteria by the balance of light and nutrients. Aquat Microb Ecol. 1999;17:27-35.

36. Levy JL, Stauber JL, Wakelin SA, Jolley DF. The effect of bacteria on the sensitivity of microalgae to copper in laboratory bioassays. Chemosphere. 2009:74:1266-74

37. Skerratt JH, Bowman JP, Hallegraeff G, James S, Nichols PD. Algicidal bacteria associated with blooms of a toxic dinoflagellate in a temperate Australian estuary. Mar Ecol-Prog Ser. 2002;244:1-15.

38. Su JQ, Yang XR, Zheng TL, Tian Y, Jiao NZ, Cai LZ, et al. Isolation and characterization of a marine algicidal bacterium against the toxic dinoflagellate Alexandrium tamarense. Harmful Algae. 2007;6:799-810.

39. Wang X, Gong L, Liang S, Han X, Zhu C, Li Y. Algicidal activity of rhamnolipid biosurfactants produced by Pseudomonas aeruginosa. Harmful Algae. 2005:4:433-43.

40. Kang YH, Kim JD, Kim BH, Kong DS, Han MS. Isolation and characterization of a bio-agent antagonistic to diatom, Stephanodiscus hantzschii. J Appl Microbiol. 2005:98:1030-8. 
41. Manage PM, Kawabata Z, Nakano S. Algicidal effect of the bacterium Alcaligenes denitrificans on Microcystis spp. Aquat Microb Ecol. 2000:22:111-7.

42. Mayali X, Doucette GJ. Microbial community interactions and population dynamics of an algicidal bacterium active against Karenia brevis (Dinophyceae). Harmful Algae. 2002;1:277-93.

43. Amaro HM, Guedes AC, Malcata FX. Antimicrobial activities of microalgae: an invited review. In: Mendez-Vilas A, editor. Science against microbial pathogens: communicating current research and technological advances. Badajoz: Formatex Microbiology book series; 2011. p. 1272-80.

44. Kokou F, Makridis P, Kentouri M, Divanach P. Antibacterial activity in microalgae cultures. Aquac Res. 2012;43:1520-7.

45. Naviner M, Berge JP, Durand P, Bris HL. Antibacterial activity of the marine diatom Skeletonema costatum against aquacultural pathogens. Aquaculture. 1999;174:15-24.

46. Guillard RR, Ryther JH. Studies of marine planktonic diatoms. Can J Microbiol. 1962:8:229-39.

47. Han J, Wang S, Zhang L, Yang G, Zhao L, Pan K. A method of batch-purifying microalgae with multiple antibiotics at extremely high concentrations. Chin J Oceanol Limn. 2015. doi:10.1007/s00343-015-4288-2.

48. Bruckner CG, Kroth PG. Protocols for the removal of bacteria from freshwater benthic diatom cultures. J Phycol. 2009;45:981-6.
49. Minas K, McEwan NR, Newbold CJ, Scott KP. Optimization of a highthroughput CTAB-based protocol for the extraction of qPCR-grade DNA from rumen fluid, plant and bacterial pure cultures. FEMS Microbiol Lett. 2011;325:162-9.

50. DeLong EF. Archaea in coastal marine environments. Proc Natl Acad Sci USA. 1992;89:5685-9.

51. Lopez I, Ruiz-Larrea F, Cocolin L, Orr E, Phister T, Marshall M, et al. Design and evaluation of PCR primers for analysis of bacterial populations in wine by denaturing gradient gel electrophoresis. Appl Environ Microb. 2003;69:6801-7.

52. Mclnerney JO, Wilkinson M, Patching JW, Embley TM, Powell R. Recovery and phylogenetic analysis of novel archaeal rRNA sequences from a deep-sea deposit feeder. Appl Environ Microb. 1995;61:1646-8.

53. Edwards U, Rogall T, Blöcker H, Emde M, Böttger EC. Isolation and direct complete nucleotide determination of entire genes. Characterization of a gene coding for 16S ribosomal RNA. Nucleic Acids Res. 1989;17:7843-53.

54. Swift S, Downie JA, Whitehead NA, Barnard AML, Salmond GP, Williams P. Quorum sensing as a population-density-dependent determinant of bacterial physiology. Adv Microb Physiol. 2001;45:199-270.

\section{Submit your next manuscript to BioMed Central and we will help you at every step:}

- We accept pre-submission inquiries

- Our selector tool helps you to find the most relevant journal

- We provide round the clock customer support

- Convenient online submission

- Thorough peer review

- Inclusion in PubMed and all major indexing services

- Maximum visibility for your research

Submit your manuscript at www.biomedcentral.com/submit 